\title{
O "romance contemporâneo" na recristianização do estado brasileiro: Nâo desanimar! de Pedro Sinzig
}

Claudio Aguiar Almeida*

\section{RESUMO}

Buscando mobilizar os católicos na luta pela recristianização do estado brasileiro, Pedro Sinzig destacou-se na arena da imprensa exercendo papel fundamental na organização de Vozes de Petrópolis e do Centro da Boa Imprensa. Na tentativa de dialogar com um público impermeável à leitura de textos ensaísticos, o franciscano engajou-se na produçáo de textos ficcionais escrevendo, em 1911, o seu primeiro "romance contemporâneo": textos que, entremeando fatos verídicos à ficção, pretendiam conquistar novos leitores para a literatura católica. A partir da discussão do romance Não desanimar!, o artigo analisa como, nos primeiros anos da República, a literatura também foi utilizada como um agente promotor da recristianização do estado brasileiro.

Palavras-chave: Pedro Sinzig; literatura católica; recristianização da República.

\section{ABSTRACT}

Seeking to mobilize Catholics in the struggle for a re-Christianization of the Brazilian state, Pedro Sinzig stood out in the professional press by playing a key role in organizing Vozes de Petrópolis (Petrópolis' Voices) and the Centro da Boa Imprensa (Good Press Center). In an attempt to dialogue with readers impervious to essays, the Franciscan engaged in the production of fictional texts, writing his first "contemporary romance" in 1911. Such texts interwove facts and fiction, and intended to win new readers for Catholic literature. Based on the discussion of the novel Não desanimar!, this article analyzes the use of literature as a tool for the re-Christianization of the Brazilian State in the beginning of the Republican regime.

Keywords: Pedro Sinzig; Catholic literature; re-Christianization of the Republic.

Artigo recebido em 5 de agosto de 2014 e aprovado para publicação em 3 de setembro de 2014.

DOI - http://dx.doi.org/10.1590/2237-101X016030002

* Doutor em História Social pela Universidade de São Paulo (USP) e professor do Centro Universitário FIEO

(UNIFIEO) entre 1994 a 2013. São Paulo, SP, Brasil. E-mail: caguiaralmeida@gmail.com. 
Na expressão de Sérgio Lobo de Moura e José Maria Gouvêa de Almeida, a separação entre Estado e Igreja instituída pela República foi interpretada pelo clero "como uma salvação e uma ameaça" para a Igreja Católica no Brasil. Liderados por D. Antônio de Macedo Costa, num trabalho que foi acompanhado de perto pela Santa Sé, os bispos brasileiros mobilizaram-se em negociações que visavam preservar, pelo menos em parte, os direitos e privilégios que a Igreja usufruíra durante o Império. Como resultado dessas negociaçôes, a Constituiçâo de 1891 ia contra postulados da Igreja Católica legitimando o casamento civil, laicizando o ensino e secularizando os cemitérios, ao mesmo tempo que assegurava direitos fundamentais à Instituição: desaprovação do divórcio, reconhecimento das ordens e congregaçóes católicas, manutenção do patrimônio e, sobretudo, concessão de autonomia para que a Igreja pudesse reorganizar-se sem a interferência do Estado. ${ }^{1}$ Contando com o apoio do Vaticano, o clero brasileiro ganhou liberdade para criar novas dioceses e arquidioceses; fundar seminários e escolas; reabrir conventos, mosteiros e congregaçóes; editar revistas e jornais. ${ }^{2}$ Essa mobilização visava objetivos muito bem determinados: uma vez reestruturada, a Igreja estaria apta a buscar um novo pacto com o Estado, recuperando os direitos e privilégios que ela havia perdido sob o regime republicano.

Dentre os diversos seminaristas e padres estrangeiros enviados para auxiliar o clero brasileiro na reestruturação da Igreja, destacou-se Pedro Sinzig. Nascido na cidade alemã de Linz, em 1876, Pedro Sinzig transferiu-se para o Brasil, em 1893, dando continuidade aos seus estudos seráficos no Convento de São Francisco, em Salvador. Ordenado sacerdote, em 1898, foi transferido para Santa Catarina onde, em janeiro de 1902, assumiu o cargo de Guardião do Convento de Lages. Na cidade serrana, Sinzig esforçou-se em combater os inimigos da Igreja no campo da imprensa, fundando o jornal católico O Cruzeiro do Sul. O encerramento das atividades do periódico não diminuiu o ímpeto editorial e jornalístico do franciscano que, transferido para Petrópolis em fins de 1907, assumiu a direção da Tipografia da Escola Gratuita São José e da recém-criada revista Vozes de Petrópolis. ${ }^{3}$ Em 1909, Pedro Sinzig assumiu um papel de liderança na criação das duas instituiçôes que se encarregariam de promover a imprensa católica e combater a influência da "má imprensa" no Brasil: a Liga e o Centro da Boa Imprensa.

Inspirado em organizaçóes católicas existentes na Alemanha, o Centro da Boa Imprensa deveria, dentre outras atribuiçôes, "promover ediçóes de bons romances, obras apologéticas

\footnotetext{
${ }^{1}$ MOURA, Sérgio Lobo de; ALMEIDA, José Maria Gouvêa de Almeida. A Igreja na Primeira República. In: FAUSTO, Bóris (Org.). O Brasil republicano: sociedade e instituiçôes (1889/1930). Rio de Janeiro: Bertrand Brasil, 1990, t. III, v. 2 (Coleçáo HGCB). p. 323-329.

2 Sobre essa expansão no período 1890/1930 consultar MICELI, Sérgio. A elite eclesiástica brasileira. São Paulo: Companhia das Letras, 2009.

${ }^{3}$ Sobre a Liga e o Centro da Boa Imprensa consultar: ALMEIDA, Claudio Aguiar. Meios de comunicação católicos na construção de uma ordem autoritária: 1907/1937. Tese (Doutorado em História) — FFLCH- USP, São Paulo, 2002.
} 
e outros livros de sã literatura, originais e traduçôes". ${ }^{4}$ No presente artigo analisaremos o romance Não desanimar!, cuja primeira edição, pelas Vozes de Petrópolis, data de 1911. Como veremos a seguir, na ausência de escritores que pudessem levar a cabo a missão de produzir uma "sã literatura" no Brasil, Pedro Sinzig engajou-se, ele próprio, na produção de "romances contemporâneos" que deveriam, ao lado das revistas e dos jornais, contribuir para o processo de recristianização da sociedade brasileira.

Nascido na Alemanha, Pedro Sinzig tinha estreito contato com instituiçóes católicas do país que lhe forneciam modelos, quando não os recursos, para estruturar a imprensa católica no Brasil. Como no caso da imprensa, os esforços de Pedro Sinzig em utilizar a literatura como um instrumento de recristianizaçáo da sociedade brasileira devem ser analisados numa perspectiva que contemple projetos congêneres desenvolvidos na Alemanha. Considerando que ela possuía um grande "poder de mudar normas", podendo contaminar os bons católicos com o "negativo pensamento relativístico moderno" e até mesmo "levar à revolução", os católicos alemães dedicavam um grande interesse à literatura, que ocupava um lugar de destaque na pauta de publicaçóes como Stimmen der Zeit, Hochland, Der Graal e outros títulos de menor expressão. ${ }^{5}$ Essa preocupação manifestou-se também na edição de livros como Konfessionelle Brunnenvergiftung: Die wahre Schmach des Jarhunderts, de Heinrich Keiter, para quem as novelas de ficção mereciam uma atenção muito maior do que a atribuída aos ensaios, uma vez que elas formavam a "opiniáo pública", definiam "as tendências e a cultura de uma época" e determinavam "o relacionamento dos homens com a religião". Na opinião do autor os "livros mais perigosos não são os de Strauss ou Renan, Nietzsche ou Haeckel, mas as novelas, que despertam em todos os homens uma febre duradoura, as ditas 'obras de arte' que inoculam nas profundezas das almas o que existe de mais baixo e mais hostil”. ${ }^{6}$

A criação de uma "literatura católica" que, ao lado de organismos de censura e bibliotecas que disponibilizassem "livros adequados" ao povo, se encarregasse de combater a "má literatura" foi objeto de grande polêmica entre os intelectuais alemáes. Apresentadas de forma embrionária no panfleto Wenn gehört die Zukunft? Ein literaturbild der Gegenwart (1893) e depois desenvolvidas no livro Steht die Katholische Belletrist auf der Höhe der Zeit (1898) e nas páginas de Hochland, as propostas de Karl Muth se destacaram nesse debate.

Na perspectiva de Karl Muth, a reflexão sobre o desenvolvimento de uma literatura católica na Alemanha deveria partir do diagnóstico de que a produção então existente não reunia condiçôes de competir com a literatura "laica". Caracterizada pelo "puritanismo" excessivo,

\footnotetext{
${ }^{4}$ SINZIG, Pedro. Passo decisivo. In: Vozes de Petrópolis, p. 439 a 445, jul. 1909 a jun. 1910.

${ }^{5}$ Fundado por jesuítas na década de 1860, o jornal Stimmen aus Maria-Laach foi obrigado a transferir sua redação para Bélgica, Luxemburgo e Holanda durante a Kulturkampf, retornando à Alemanha em 1914, momento em que adotou o nome, Stimmen der Zeit, e o perfil que se tornaram referência para a criação da revista Vozes de Petrópolis. O jornal Hochland foi fundado em 1903 e o Der Graal em 1906. Consultar a respeito DALTON, Margareth Stieg. Catholicism, Popular Culture, and the Arts in Germany: 1880-1933. Notre Dame: University of Notre Dame Press, 2004, p. 63-64.

${ }^{6}$ Apud DALTON, Margareth Stieg, op. cit., p. 58.
} 
ausência de virtudes literárias e humor, a literatura católica alemã não conseguia agradar sequer aos adeptos da religiáo: os católicos dotados de uma educação mais refinada preferiam consumir obras de qualidade literária superior, enquanto os "menos educados" revelavam uma preferência cada vez mais acentuada pela Unterhaltungsliteratur ("ficção leve"), Schund e Shmutzliteratur (literatura "barata" ou "pornográfica") e meios de diversão, como o cinema e o rádio, que requeriam um menor esforço intelectual. Contrapondo-se a intelectuais ultramontanos que o acusavam de ser um defensor da "arte pela arte", 7 Karl Muth propugnava o aprimoramento artístico e a busca de uma maior sintonia com as questóes do presente como condiçôes fundamentais para o desenvolvimento da literatura católica alemã. Só assim ela conseguiria concorrer com a "má literatura", rompendo as limitadas fronteiras em que permanecia restrita e contribuindo efetivamente para a propagação do catolicismo. Cabe destacar, no entanto, que esse aprimoramento da literatura católica esbarrava em dificuldades. Se a falta de qualidades artísticas da literatura católica criava barreiras para a expansão do número de seus leitores, a insignificância do público católico também criava barreiras para o seu aprimoramento artístico. Ainda que tivessem suas rendas complementadas por doaçôes de fiéis ou do episcopado, e se orgulhassem de afirmar que seu trabalho visava à glória de Deus e não ao lucro material, escrever e publicar para os católicos implicava, quase sempre, prejuízos que afastavam editores e escritores profissionais do gênero.

Acompanhando com grande interesse os debates travados pelos católicos alemães, Pedro Sinzig empenhou-se no combate à "má literatura" e no incentivo à produção e propagação da literatura católica no Brasil. Publicado em 1915, o livro Através dos romances: Guia para as consciências nos permite analisar não só as estratégias de censura e orientação do público, mas também traços característicos da produção literária que Pedro Sinzig vinha desenvolvendo desde 1911. O autor introduz a segunda ediçáo da obra narrando a estória de uma menina morta em decorrência da ingestão de maçãs que, "para terem as faces vermelhas", haviam recebido uma forte injeção de veneno. $\mathrm{O}$ mesmo se dava com relação aos livros que, qual "maçâs de faces rosadas", exerciam "irresistível fascinação" sobre "mocinhas" que, inadvertidamente, acabavam elas também envenenadas por leituras inadequadas. Se a venda de maçãs envenenadas exigia providências das autoridades policiais, o consumo de "romances

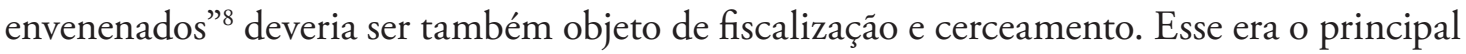
objetivo do Através dos romances: Guia para as consciências: indicar, a partir da análise de uma extensa lista de autores e títulos, as leituras que eram ou não adequadas às diversas faixas do público católico.

\footnotetext{
${ }^{7}$ Nas críticas a Karl Muth vão se destacar os redatores do Der Graal cujos membros se caracterizavam pelo "culto ao passado [...], lealdade aos ideais da Idade Média" e produção de uma "literatura fora de moda". DALTON, Margareth Stieg, op. cit., p. 67.

${ }^{8}$ SINZIG, Pedro. Através dos romances: Guia para as consciências. Petrópolis: Vozes de Petrópolis, 1923. p. 3-4.
} 
Náo nos cabe analisar mais a fundo os critérios utilizados por Pedro Sinzig na avaliaçáo dos escritores e livros de Através dos romances. ${ }^{9}$ No que se refere ao caso específico da "literatura católica", no entanto, é necessário destacar que, como Karl Muth, Pedro Sinzig apontava o excesso de "puritanismo" como um dos seus principais problemas. Na introdução do seu Guia para as consciências, Pedro Sinzig transcreve um texto do padre e escritor Luiz Coloma em que esse excesso de moralismo é combatido:

Eu deixei correr a minha pena com inteira indiferença, repelindo horrorizado da minha pintura essa teoria perversa que corrompe o critério da moralidade [...]; porém igualmente te confesso que se não foi com espanto, foi ao menos com grande fastio e até com certa ira literária (grifo do autor), que repeli também o outro extremo contrário, próprio de algumas consciências timoratas, que se empenham em achar perigo onde quer que apareça algo de deleitável. Se erram os primeiros, não vendo abismos onde se encontram flores, também me parece que erram os segundos por excesso de medo, não concebendo uma flor sem que oculte um precipício. E assim, partindo uns de um princípio falso e outros de uma verdade santa, passam todos da exageração ao engano, e logo depois à demência, parecendo aquelas que as cruezas de Zola podem servir de guia à mocidade, e julgando estes que não convém ensinar às crianças o Credo e os Artigos da Fé, sem introduzir primeiro certas prudentes modificações, de que te poderia citar algum ridículo exemplo. ${ }^{10}$

Como Karl Muth e Luiz Coloma, Pedro Sinzig tinha consciência da necessidade de se dotar a literatura católica da "ira literária", das "flores" e do "algo deleitável" que se faziam presentes em outros gêneros. A necessidade de combater o mal disseminado pelos romances, pelo teatro e pelo cinema impunha novos desafios aos romancistas católicos, exigindo-lhes ousadia e inteligência na escolha e tratamento de temas que, embora polêmicos, não poderiam ser ignorados por obras que pretendessem dialogar com um público mais amplo. $\mathrm{O}$ atendimento dessas exigências estaria na origem do impulso alcançado pela literatura católica alemã que, finalmente, reunia condiçóes de se impor "a amigos e inimigos". Resenhando Filho de Agar, de Paulo Keller, Pedro Sinzig exalta as qualidades que o credenciavam como um paradigma para o desenvolvimento do romance católico na Alemanha e no Brasil:

\footnotetext{
${ }^{9}$ Essa tarefa já foi realizada por outros autores, como: PAIVA, Aparecida Paiva. A voz do veto: a censura católica de romances. Belo Horizonte: Autêntica, 1997 e SANTOS, Maria Margarete dos. Os jardins abençoados de um franciscano, discurso sobre a leitura de Frei Pedro Sinzig: 1915-1923. Dissertação (Mestrado em História) — USP, São Paulo, 2005.

${ }^{10}$ SINZIG, Pedro, op. cit., p. 4. Esse texto já havia sido anteriormente transcrito pelo autor na revista Vozes de Petrópolis. Ver SINZIG, Pedro. Os romances das Vozes de Petrópolis. Vozes de Petrópolis, Petrópolis, p. 1095-1098, jul./dez. 1912.
} 
O autor não escolheu por assunto o adultério, a infidelidade [...] que está na moda, e do qual tanto se queixam todos os elementos sérios da sociedade.

Trata de outro problema: mostra as tristes consequências duma falta cometida na mocidade. $\mathrm{O}$ Filho de Agar é o Filho que não tem pai.

Salta aos olhos a enorme diferença entre o romance de Paulo Keller e os que por aqui geralmente se entendem sob o nome de "romance francês".

Keller, por mais realista que seja, não dá nunca ao vício o brilho da fascinação que tão prejudiciais torna outros romances. Nem mesmo descreve a falta cometida, dando-a apenas como fato real do passado.

Quanto ao assunto em si e o modo sério com que é tratado, convém (ainda) lembrar o seguinte: A virtude da pureza não consiste na ignorância do mal, e sim na resistência a tudo que rebaixa. Os perigos que ameaçam a virtude, hoje em dia, são tão grandes que ninguém lhes pode fugir, nem mesmo que se encerre dentro das paredes de um lar honesto. O perigo ameaça nos jornais que entram em casa, nos postais ilustrados, nas gravuras e imagens, nos cinemas e teatros, em muitas vitrinas, nos cartazes nas paredes nos ditos proferidos na rua. É indispensável, pois, a resistência interna: detestar o mal, apresente-se ele onde e como for. ${ }^{11}$

Malgrado seus esforços, a Igreja não havia conseguido impedir a propagação do pecado pela literatura, jornal, teatro, cinema e outros meios de comunicação. Ciente dos limites de suas iniciativas no campo da censura, Pedro Sinzig defendia o desenvolvimento de uma literatura católica que, buscando uma maior sintonia com as questóes do seu tempo, combatesse o mal em vez de ignorá-lo. Num contexto em que até mesmo as almas mais virtuosas estavam expostas aos "perigos que ameaçam a virtude", cabia ao romancista católico enfrentar a tarefa de combatê-los, expondo as "tristes consequências" da opção pelo mal.

Definido o perfil da nova literatura católica, fazia-se necessário recrutar os escritores que poderiam desenvolvê-la no Brasil. Em 1911, procurando revelar novos talentos no campo da literatura voltada ao público feminino, Vozes de Petrópolis abriu um concurso que premiaria a "melhor peça dramática sobre o tema Só a prática da religião torna a mulher feliz". ${ }^{12}$ Os resultados, segundo Pedro Sinzig, não foram muito animadores: julgando que nenhum dos trabalhos tinha "condiçôes de ganhar o primeiro ou o segundo prêmio", a comissão julgadora do concurso concedeu ao texto de Ancilla Domini, pseudônimo de Hilda Leite Guimarães, apenas o terceiro. ${ }^{13}$ Pedro Sinzig voltaria a apostar na possibilidade de consoli-

\footnotetext{
${ }^{11}$ SINZIG, Pedro. Notas sobre O Filho de Agar. In: Vozes de Petrópolis, p. 1027-1028, jul./dez. 1912.

${ }^{12}$ Ver Concurso Literário. Vozes de Petrópolis, Petrópolis, p. 131, jul./dez. 1911.

${ }^{13}$ Incentivada por Pedro Sinzig, no entanto, Ancilla Domini procurou superar suas deficiências assumindo um papel de relativo destaque no campo da literatura católica, até o seu falecimento em fins de 1916. Ver SINZIG, Pedro. Ancilla Domini. In: Os nossos escritores. Rio de Janeiro: Centro da Boa Imprensa, 1917. p. 23-34.
} 
dar um nome de destaque na literatura católica, incentivando, em 1923, ${ }^{14}$ a escritora baiana Amélia Rodrigues a transferir-se para Niterói. Também nesse caso, os resultados da iniciativa estiveram aquém dos esperados: sem encontrar os recursos que lhe permitiriam dedicar-se exclusivamente à literatura, Amélia Rodrigues foi forçada a retornar à Bahia no ano de 1925. ${ }^{15}$ Com uma intensa atividade no campo jornalístico, político e paroquial Pedro Sinzig talvez preferisse restringir suas atividades literárias à orientação e edição de bons livros. No entanto, muito provavelmente em função da inexistência de leigos que pudessem escrevê-los, Pedro Sinzig viu-se forçado a aventurar-se, ele próprio, na produção de romances. Na apresentação da terceira edição do seu primeiro romance, Não desanimar!, Pedro Sinzig reflete sobre sua investida num campo que ele havia sido "obrigado" a explorar:

Até pouco antes de pegar na pena para escrever o Não desanimar! nunca me havia passado pela cabeça que, um dia, escreveria eu algum conto mais desenvolvido, ou até um romance. Muito pelo contrário, tinha tal admiraçáo pelos autores de romances, que julgava demasiadamente despida de recursos a minha fantasia, para pensar em segui-los nesse terreno.

Uma longa viagem ferroviária, porém, de Curitiba a Sáo Paulo, fez-me ler com atenção e interesse o belo romance de Ansgar Albing (Monsenhor Paulo, Baráo Von Mathies): Moribus Paternis [...]. Achei tudo quanto dizia esse privilegiado escritor tão natural, tão simples, tâo espontâneo, táo tirado da vida de cada dia, que, pela primeira vez, me surgiu a ideia: E se tentasse outro tanto?...

Pus-me a recordar fatos reais, a concatená-los e, terminando mais ou menos o quadro na imaginação, fui fixá-lo com a pena, dentro de um mês, mais ou menos: Não desanimar!! ${ }^{16}$

Com Não desanimar! Pedro Sinzig deu início à produção de um gênero literário que ele veio conceituar como "romance contemporâneo": ${ }^{17}$ obras que, entremeando fatos verídicos à ficção, edulcoravam a análise de temas da atualidade, tornando-a acessível a um público que náo nutria maior interesse por obras de cunho ensaístico. Embora reconhecesse o papel dos romancistas para a formatação do "romance contemporâneo", Pedro Sinzig fazia questão de destacar como o gênero não era estranho aos clérigos que, ainda que inconscientemente, recorriam com frequência à "fantasia":

\footnotetext{
${ }^{14}$ Cabe ainda destacar que, no segundo semestre de 1913, Vozes de Petrópolis promoveu um novo concurso literário com o tema "A Imprensa". Ver Vozes de Petrópolis, p. 943, jul./dez. 1913.

${ }^{15}$ Amélia Rodrigues faleceu em Salvador no ano de 1926. Ver PAIVA, Aparecida, op. cit., p. 127-153.

${ }^{16}$ SINZIG, Pedro. Não desanimar!. 3. ed. Petrópolis: Vozes de Petrópolis, 1925. p. 3. Todas as indicações de página referem-se a essa edição da obra.

${ }_{17} \mathrm{O}$ termo parece ter sido cunhado pelo próprio Sinzig. Em sua terceira edição Não desanimar! carrega o subtítulo Romance contemporâneo brasileiro, que também é aplicado a Pela mão de uma menina. Tratando de eventos ocorridos fora do Brasil, Ai! Meu Portugal e Tempestades são apresentados como "Romances Contemporâneos", enquanto Guerra!!! é classificado como um "Quadro da Atualidade".
} 
Já leste, meu amigo, 'O Filho do Homem, episódios da vida de Christo' por Anna, Baronesa Von Krane? [...]

Anna Von Krane, — e o mesmo fizeram outros distintos escritores como Monlaur, Pfannmüller, Jörgensen, Hoehler, etc. — baseando-se em dados positivos e tomando em consideração os costumes do país e as condiçóes da época, completa o quadro que das máos dos historiadores recebeu somente em contornos, criando então algo de palpável, com vida própria, a fim de despertar mais interesse no comum dos leitores, do que o fazem páginas pesadas e por isso talvez pouco atraentes.

Não abandona jamais o fundamento histórico, mas onde este apresenta falhas, recorre à imaginação que, frutificada pelo estudo, logra completar a cena.

É novo o método? Não é. Não há pregador nem catequista que não o siga, por mais averso (sic) que se diga a 'fantasias'; apenas, nem todos para isso dispóem dos recursos d'uma Monlaur ou d'uma Von Krane. Os próprios biógrafos, que parecem cingir-se rigorosamente a fontes históricas, dão algo da sua fantasia, para completar episódios por demais resumidos. Assim, Chérancé, contando a chegada de $S$. Antônio à África, escreve:

'Quando S. Antônio viu, pela primeira vez, a costa africana, sentiu uma impressão indescritível de gozo'.

D’onde colheu o biógrafo essa informação? A não ser por uma revelação, não é possível que tenha tido ciência dos sentimentos de $S$. Antônio, o que, entretanto, náo o impede de o atribuir ao Santo e de analisar determinados pensamentos, que o teriam invadido a quando de sua chegada à África.

Facílimo é citar casos análogos das biografias mais em voga.

Sigo, pois, consciente e alegremente este caminho, por grande que seja a distância que vai da minha pena, de pobreza franciscana, aos fulgores da de Anna Von Krane e outros cultores desse simpatizado gênero. ${ }^{18}$

Embora se referindo a outro gênero, as observaçóes de Pedro Sinzig a respeito de sua hagiografia de Santo Antônio nos ajudam a compreender a forma e as funçôes que o franciscano atribuía ao "romance contemporâneo". Sem abandonar o "fundamento histórico" o biógrafo - tal qual o romancista, pregador ou catequista — podia utilizar a "imaginação" e a "fantasia" para completar as lacunas e corrigir as "falhas" presentes em textos históricos, jornalísticos ou hagiográficos. Além de conferir uma maior legibilidade a narrativas caracterizadas pelo seu caráter lacunar, a estratégia aproximava os leitores de fatos e ambientes que lhes eram espacial ou temporalmente distantes. Os eventos do passado, e também os do presente, tornavam-se mais "palpáveis" e ganhavam "vida própria" despertando maior interesse no "comum dos leitores".

\footnotetext{
${ }^{18}$ SINZIG, Pedro. Para orientar o leitor. In: O thaumaturgo Santo Antonio. Petrópolis: Centro da Boa Imprensa, 1922. p. 5.
} 
Em Não desanimar! fatos, conflitos e personagens da história brasileira e mundial, incluindo-se aqui o próprio Pedro Sinzig, ${ }^{19}$ se entrecruzam numa narrativa que, como já foi dito, pretendia ampliar o público consumidor da literatura católica, oferecendo diversão e encantamento a leitores que não tinham disposição para enfrentar a aridez dos livros e artigos ensaísticos. ${ }^{20}$ Num dos intervalos da ópera Oberon, encenada no teatro real de Wiesbaden, o advogado Antônio da Costa Barros encontra um casal de brasileiros: o comendador Marcos de Castro Moreira e sua filha Judith. O prazer proporcionado pelo encontro acidental de brasileiros em terras estrangeiras resulta num animado bate-papo em que Antônio da Costa Barros revela estar se dirigindo à Oberammergau. Animada com a possibilidade de também assistir à célebre Paixão ali encenada, Judith convence seu pai a unir-se ao programa sugerido pelo novo amigo.

A breve descrição do primeiro capítulo de Não desanimar! nos permite apontar um traço recorrente dos "romances contemporâneos" de Pedro Sinzig: a eleição de membros da elite brasileira como seus personagens principais. A resistência de Marcos de Castro em assistir à Paixão de Oberammergau, por sua vez, aponta para tensóes inerentes a essa elite que Pedro Sinzig pretendia, com o auxílio de seus romances, modificar. Membro da maçonaria, o comendador não manifesta maior interesse em assistir ao espetáculo da Paixão, só concordando em fazê-lo por insistência da filha Judith: jovem que, sem ter sucumbido às tentaçôes que pontuavam o cotidiano das mulheres de mesmo status social, permanecera fiel aos ideais do catolicismo. Antônio da Costa Barros, por sua vez, não tinha um perfil muito diferente de Marcos de Castro revelando-se, ele também, um descrente. Ao assistir à Paixáo de Oberammergau e verificar o efeito que tal espetáculo exercia sobre Judith, no entanto, o personagem tem sua incredulidade abalada por um breve momento:

Antônio, contemplou [...] sua gentil vizinha (Judith), invejando-lhe o ardor da fé sincera: — E se Cristo fosse realmente Deus!... Se os padres tivessem razão!... Mas, não pode ser. Cristo sugestionou as massas por sua bondade inexcedível, por perdoar sempre, e a tudo e a todos, por não ofender jamais a ninguém, por não pronunciar nunca uma palavra áspera... eis tudo!... (p. 21)

\footnotetext{
${ }^{19} \mathrm{Na}$ apresentação da primeira edição do livro, Pedro Sinzig adverte seus leitores para a estreita ligação da obra com o momento histórico em que ela fora produzida: "Embora me tenha servido da licença concedida aos romancistas, a maioria de todos os episódios narrados nestas folhas baseia-se em fatos reais. Nas cenas históricas preferi servir-me das próprias palavras que constam de atos oficiais ou da imprensa". SINZIG, Pedro. Não desanimar!, p. 5. Essa introdução à primeira edição do livro é datada de “7, XIII (sic). 1911".

${ }^{20}$ Referindo-se à "grata impressão" que a leitura de Não desanimar! e Pela mão de uma menina teriam causado em sua "adolescência", Brito Broca sugere que os objetivos perseguidos por Pedro Sinzig teriam sido alcançados: "Vi-os (os romances de Frei Pedro), como verdadeiros romances de aventuras. Outras aventuras, diferentes daquelas de Júlio Verne, nem por isso menos sedutoras, eis o que o bom frade me contava em seus livros. E para que eu os sentisse e os visse sob esse aspecto, era preciso que estivesse em estado de graça... Não se admirem, pois, que nos livros de um frade eu aprendesse a ler romances”. Brito Broca, apud BEUTTENMÜLLER, Leonila Linhares. Frei Pedro Sinzig O.F.M. Petrópolis: Vozes, 1955.
} 
Descrevendo cenas da Paixáo, e os efeitos que elas causavam sobre seus espectadores, Pedro Sinzig coloca em evidência o poder de conversão de narrativas dramáticas capazes de falar às emoçốes e aos sentimentos. Nem mesmo Antônio e o comendador Marcos de Castro conseguiriam resistir à torrente de emoçôes que, dissolvendo as fronteiras entre "ficção" e "realidade", contaminava os espectadores da encenação.

Agora...

Judith, em todo seu ser sensível e vibrátil, estremece, até as pálpebras, onde tremulam límpidas gotas do orvalho celeste que são as lágrimas por amor de Jesus e de Maria... O próprio cético e crítico Dr. Antônio, como o comendador, sentem-se tocados de irreprimível comoção... A Mãe de Jesus veio despedir-se do Filho, sobre tudo amado e sobre todos...

Em revistas ilustradas, em cartóes postais, em fotografias, Antônio já muitas vezes vira reproduzidas as feições de Ottilia Zwink, que, em 1910, figuraria Maria Santíssima, e — não lhe agradara. Aquela... representar a Virgem Mãe?...

Mas, hoje... agora... seria aquela a mesma que ele de antes conhecia?... Impossível!... O que ali, diante de seus olhos maravilhados, se passava, não lhe parecia fição, mas sim perfeita realidade. Os espectadores, aos milhares, nem ousavam respirar. Silêncio absoluto pesava em toda a amplíssima plateia, estendia-se ao cenário... e apenas de tempo a tempo, o ruído seco do virar das páginas do libretto, ou, cada vez menos abafado, um soluço, outro, mais outro, ali, mais longe, contido a princípio este, aquele quase se desabotoando em pranto... (Grifo nosso, p. 22-23)

Sintonizado com a Paixão, Antônio não a encara mais como uma "ficção", reconhecendo-a agora como a "perfeita realidade". Essa mudança de perspectiva do personagem nos ajuda a compreender os objetivos que Pedro Sinzig procurava atingir com sua narrativa: mesclando fatos verídicos com ficção, obras como Não desanimar! deveriam provocar em seus leitores efeitos semelhantes aos produzidos em Antônio, Marcos de Castro e Judith pela Paixão de Oberammergau. Com um poder de sedução muito superior ao ensaio, os "romances contemporâneos" atuavam diretamente nas emoçóes dos seus leitores, tornando-os mais permeáveis à assimilação da doutrina católica. Embora, em seu isolamento, não pudessem se contaminar com a torrente de emoções que, em espetáculos de fruição coletiva como a Paixão, se irradiavam por toda a plateia, os leitores dos "romances contemporâneos" poderiam ter suas convicçóes e comportamento modificados por textos dotados de forte intensidade dramática.

Voltemos aos nossos personagens. Após a experiência proporcionada por Oberammergau, Marcos de Castro, Judith e Antônio iniciam seu retorno ao Brasil embarcando no paquete Cap Arcona: mesmo navio utilizado por Pedro Sinzig quando de sua viagem à Europa no ano de 1910. Como veremos a seguir, essa "coincidência” não era acidental. Utilizando estratégias típicas dos “romances contemporâneos", Pedro Sinzig trabalhará, num estilo ficcional, fatos que 
ele havia vivenciado numa rápida passagem por Lisboa durante a "Revolução Republicana". Descrita no livro Reminiscências dum frade, a citada passagem teria se resumido a um tenso passeio pelas ruas da cidade. ${ }^{21}$ Complementadas por depoimentos e notícias posteriormente publicadas em jornais, as impressóes de Pedro Sinzig sobre a "Novel República Portuguesa" assumiriam em Não desanimar! um tom mais dramático e aventuresco.

Marcos de Castro e Antônio desembarcam em Lisboa, observando, consternados, a desordem e a falta de "entusiasmo espontâneo da massa, do verdadeiro povo, pelo advento das novas instituiçôes democráticas" que só encontravam manifestaçôes de apoio entre "bandos de soldados ou grupos armados [...] formados por indivíduos de caras patibulares e ameaçadoras". Impedidos de visitar os Jerônimos pela ausência de transporte, Marcos de Castro e Antônio resolvem visitar uma Igreja, constatando que a mesma estava sendo depredada por "carbonários":

O tabernáculo, aberto, fora evidentemente profanado. O cibório de ouro, despojado das sagradas Hóstias, fora miseravelmente injuriado a servir de... vaso noturno!...

O comendador, presa de irresistível acesso de cólera, exclamou:

- Eu sou republicano e maçom, mas isto é diabólico!

— Canalhas! — gritou o doutor em voz forte. (p. 41)

Os "carbonários avançam contra os brasileiros", mas Antônio consegue desarmá-los, ordenando ao comendador que retornasse ao porto. Vencido em uma luta desigual, Antônio estava prestes a ser executado quando foi salvo pelo tenente Alfredo Mourão, que se encarregou de conduzi-lo, ferido, até o Cap Arcona:

— O senhor teve sorte! — disse-lhe (o médico de bordo); — estes republicanos... raios os partam!... felizmente náo sabem atirar... Foi agredido na rua?

— Náo; tive de defender-me quando, indignado, pela inaudita profanação de uma igreja, apostrofei-os, como canalhas que efetivamente são.

— Apoiado! Então, o senhor é católico... como se diz... crente?

- Nasci no catolicismo, Sr. doutor; mas os estudos fizeram-me abandonar as práticas religiosas e tornar-me um livre pensador.

— Mas, como entáo o revoltou tanto a profanaçáo de um lugar que deixou de lhe ser sagrado? - Ah! Para isso não é preciso ser crente! Basta ser-se homem de bem e respeitar as crenças alheias. De mais a mais, o catolicismo sempre me merecerá alguma simpatia, por ser a religiáo de minha mãe, que a pratica, que por ela vive, que por ela daria a própria vida...

— Muito bem, meu amigo. Vejo que é homem que se preza e é bom filho. Não conheço o Brasil, mas se todos os brasileiros são como o senhor, não posso deixar de lhes querer bem. (p. 51)

${ }^{21}$ Ver SINZIG, Pedro. Reminiscências dum frade. Petrópolis: Vozes de Petrópolis, 1925. p. 420-426. 
Formado na tradição do catolicismo, Antônio havia se afastado da doutrina que assimilara em seu berço tornando-se um "livre pensador". Sob o influxo da mãe, de Judith e de experiências como as de Oberammergau e Lisboa, no entanto, esse catolicismo expungido por uma educação laica poderia voltar a florescer, fazendo com que não apenas Antônio, mas também os leitores de Não desanimar!, se reencontrassem com a fé católica. Ao lado do comendador Marcos de Castro, Antônio da Costa Barros personifica as elites da sociedade brasileira que Pedro Sinzig pretendia recristianizar utilizando, dentre outras armas, o "romance contemporâneo".

No convés do Cap Arcona, os passageiros do navio se divertem com a possibilidade de participar de uma "corrida" contra o Aragon: navio da marinha real inglesa que, mesmo tendo partido dez horas antes do Cap Arcona, estava sendo ultrapassado pelo navio alemão. Em busca de entretenimento, alguns passageiros incentivam Judith a falar sobre a Paixão de Oberammergau: espetáculo que, segundo ela, tivera "uma das cenas [...] reproduzida, não no palco, mas na vida real". Procurando elucidar a afirmação da filha, o comendador Marcos de Castro narra a "cena" por ele presenciada na Lisboa Republicana: "à passagem dolorosa de pobres frades presos e insultados e apedrejados pelos carbonários, com um furor análogo ao dos judeus contra Cristo".

A menção às perseguiçóes dos jesuítas pela República Portuguesa leva os passageiros a se indagarem sobre frei Estevam: padre franciscano embarcado no Cap Arcona. Ao procurar, a pedido de Judith, informaçóes sobre o horário da realização das missas no navio, Antônio tem a oportunidade de debater questóes religiosas com o clérigo:

- A filha do meu amigo desejaria saber a hora da missa amanhã.

—Começará às $9 \frac{1}{2} \mathrm{em}$ ponto, no salão.

- Agradecido, reverendo. Ela ficará satisfeita de assim cumprir uma obrigação própria do seu sexo.

— Ah! Uma novidade para mim, senhor... se me permite, com quem tenho a honra de falar?

- Antônio da Costa Barros, doutor em direito.

— E eu, Frei Estevam, da Ordem de São Francisco... Pois, o doutor realmente me traz uma novidade que me interessa...

— De que a moça é piedosa?

— Não; isso absolutamente não me surpreende; mas de que a prática da religiâo é obrigaçẫo só para o sexo feminino.

- Modos de ver, Sr. Padre. Eu não desconheço a conveniência do sentimento religioso na mulher; mas o homem, de organizaçáo física táo diferente, talhado e aparelhado para as grandes lutas da vida e das conquistas científicas, é chamado a outro... como dizer? Tem outra vocação, deve mesmo libertar-se de... perdoe a franqueza!... de preconceitos religiosos. (p. 58-59) 
"Vítima" da educação laica e das "más leituras", Antônio havia sido condicionado a acreditar em "inverdades" que frei Estevam, com seu discurso habilidoso, procura combater. Ganhando maior visibilidade no século XVIII com o advento do Iluminismo e da Revolução, ${ }^{22}$ a crença na incompatibilidade entre Fé e Razão estaria na origem da pretensa inadaptabilidade dos homens ao catolicismo: "talhados" para as "conquistas científicas", os homens eram impermeáveis à assimilação de doutrinas que não houvessem sido construídas pelo saber racional enquanto as mulheres, governadas mais pelo sentimento que pela razão, eram muito mais propensas a aderir, como "uma obrigação própria do seu sexo", aos dogmas que lhe eram ditados pela Igreja Católica.

Antônio e frei Estevam continuam seu debate, enquanto a aproximaçáo do Cap Arcona do Aragon agita os outros passageiros e a tripulação. Acompanhada pela execução do Deustshcland über alles, a ultrapassagem do navio inglês pelo alemão ofereceu aos passageiros a oportunidade de conhecer uma nova faceta do franciscano, que juntou sua voz ao coro que entoava o hino nacional alemão: embora fosse agora "brasileiro", explicou frei Estevam aos passageiros que estranharam seu comportamento, ele havia nascido na Alemanha, terra amada onde deixara os que lhe eram "mais caros [...] no mundo".

Navegando em alta velocidade, o Cap Arcona chega ao Rio de Janeiro no mesmo momento em que, no largo de São Francisco, o senador Coelho realizava um "meeting anticlerical". Comparado aos espetáculos realizados "nos circos de cavalinhos, nos teatros de burla e arte barata, e nas casas de schops e cançonetas de ínfima classe, onde a falta de pudor só é igualada pela ausência de qualquer resquício de arte", o comício mobiliza as emoçóes das "massas populares" que obedecem à palavra de ordem lançada pelos organizadores do evento: atacar as freiras do Convento da Ajuda:

- Morram as freiras! - berravam alguns mais loucos, desfechando valentemente seus revólveres contra as grossas muralhas silenciosas do mosteiro. Com pesados cacetes e bengalas martelavam fragorosamente nas portas largas da entrada, enchendo de terror as míseras religiosas ali recolhidas em recato e oração, e que se sentiam ameaçadas por todo aquele grande grupo desvairado de anticlericais em delírio. (p. 67)

Em meio à confusão, que do centro da cidade se estendera ao porto, os passageiros do Cap Arcona assistem, ainda no cais, à chegada da "escolta" que se encarregaria de conduzir frei Estevam em segurança ao convento de Santo Antônio.

Convidado a hospedar-se na residência dos Castro Moreira, Antônio tem a oportunidade de conhecer os outros membros da família do comendador: sua esposa Sinhá, sua filha

\footnotetext{
${ }^{22}$ Além de merecer destaque nas páginas de Vozes de Petrópolis, o tema da incompatibilidade entre Fé e Razão foi objeto de um livro publicado no mesmo período: DESCHAND, Desidério. Os grandes sábios e a fé na época contemporânea. Tournai: Sociedade de S. João Evangelista/Desclée e Cia, s/d.
} 
Dulce e seu filho Carlinhos. Inquirido pelos Castro Moreira, Antônio fala sobre um pouco sobre a mãe e irmã que o aguardavam ansiosamente em Santa Catarina.

A partir da referência à família de Antônio, Não desanimar! se desloca para o planalto catarinense. Entrelaçando, mais uma vez, realidade e ficção, Pedro Sinzig recupera fatos marcantes de sua passagem pelo Convento de Lages através do personagem frei José: franciscano que, regressando de uma longa e desconfortável jornada, náo hesita em se dirigir à fazenda São Januário para prestar socorro à família do Dr. Antônio de Barros. As bruscas mudanças de temperatura e o inverno rigoroso, típicos da regiáo, haviam contribuído para a deterioração da saúde de Helena e de sua filha Trudinha ${ }^{23}$ que administravam a fazenda da família desde que Antônio de Barros viajara para a Europa. Embora a saúde de Trudinha estivesse também abalada, o agravamento no estado geral de D. Helena é que havia motivado o chamado de urgência a frei José. Reanimando-se depois de ter se confessado e assistido uma missa celebrada pelo franciscano, a matriarca expóe alguns dos seus temores a frei José:

- Eu agora estou preparada para tudo, Sr. Padre. A única coisa que ainda me preocupa, e muito, se bem que Deus me haja perdoado todo pecado, desleixo e fraqueza, é a incredulidade de meu filho. Ele era tâo piedoso, quando pequeno! Ainda hoje é bom filho e bom irmão. Mas o colégio onde foi educado, e, mais tarde, a Faculdade de Direito, juntamente com os perigos do mundo, fizeram-lhe perder a fé. Apego-me a Nossa Senhora pra que não mo deixe perecer. Todas as minhas oraçóes, no purgatório e no próprio céu, seráo por sua conversão. E o Sr. Padre me ajudará... (p. 96-97)

Sem que Dona Helena sequer imaginasse, ela possuía outra aliada na missão de reconverter Antônio ao catolicismo: Dulce, a filha mais velha de Marcos de Castro, que trava um acalorado debate sobre religiáo com o hóspede da família. Um tanto acuado pelos argumentos da jovem católica, Antônio recebe o providencial auxílio do comendador, que intervém no debate:

— Mas que conversas são essas, minha filha! Você está aborrecendo o nosso bom amigo! — interrompeu de súbito o comendador, que chegava.

— Ora, papai, então a gente se deve sempre preocupar de coisas fúteis?!

— Em nada me importuna, meu amigo - disse Antônio - Pelo contrário, eu desejaria conseguir obter sempre destas palestras, embora me visse vencido.

— Ah! O senhor também vencido? A minha filha meteu-se-lhe na cabeça converter o mundo inteiro - disse, gracejando, o Sr. Castro.

— Oxalá pudesse eu consegui-lo papai!

— E começarias certamente por casa, não é?

${ }^{23}$ Derivado de Gertrudes, “Trudinha” era a forma carinhosa pela qual Pedro Sinzig referia-se à própria irmã. 
- Ora, papai, isso não é para gracejos...

— Então, eu sou mesmo assim tão mau?

— Tu és meu bem, meu querido paizinho que eu amo de todo o coração. Mas se tu praticasses a religião, se nos acompanhasses à mesa da sagrada Comunhão, oh! Então tu serias o melhor dos melhores de todos os pais do mundo!

- Olha, filhinha, a mesma panaceia não é útil para toda gente. A religião, para o povo baixo, para as classes inferiores, como freio a contê-las, vá lá eu admito; mas para gente instruída...

— Que atenção às tuas filhas! - disse Dulce, meio gracejando, para continuar, séria: Não são os muito instruídos que menos dela precisam. Sem religião, eles só podem tornar-se perversos e perniciosos, e é das suas fileiras que saem os defraudadores dos dinheiros públicos, os caudilhos e chefes revolucionários sem um ideal nobre; os ridículos, mas daninhos tiranetes das repúblicas novéis... e depois, papai, onde é que começa a instrução que dispensa a prática religiosa? No terceiro de engenharia de máquinas ou no segundo ano de direito? No burguês, que arrebenta e apodrece de rico e assina $O$ Malho, ou no caixeiro da esquina, que lê Emile Zola?... (p. 105-106)

O diálogo dos três personagens retoma a clássica interpretação do processo de estabelecimento da República no Brasil, em que se destaca o fosso entre as lideranças do movimento e o povo que "assistiu àquilo bestializado, atônito, surpreso, sem conhecer o que significava”. Descrito com perspicácia na célebre carta de Aristides Lobo, esse divórcio era também perceptível no campo religioso, ${ }^{24}$ marcado pelo contraste entre o catolicismo das classes populares e a apostasia das elites que identificavam a Igreja Católica ora como uma adversária, ora como uma "auxiliar" no controle das massas. Recusando os papéis que lhe eram atribuídos pelos detentores do poder, a Igreja exigia a recristianização do estado: única maneira de livrar o país da iniquidade geradora dos motins e revoltas que recrudesciam desde a proclamação da República.

Denunciada por Dulce, a apostasia das elites como um elemento desestabilizador da sociedade brasileira seria confirmada por acontecimentos que, respeitando os parâmetros dos "romances contemporâneos", envolveram personagens históricos e ficcionais: convocados por uma nota publicada no Jornal do Brasil, um grupo de maçons ser reúne na loja Silêncio Noturno com o objetivo de estabelecer as açôes futuras da "seita".

— Torna-se urgente dar um passo decisivo — disse o Ir.'. 2o Vigilante ao Ir.. Orador. — As circunstancias tornam a ocasião favorável, como jamais se nos apresentou antes. O Nilo é nosso. Depois daquele carola que era o Afonso Pena, não poderíamos encontrar quem melhor nos conviesse a favorecer-nos na tarefa de promover o bem da humanidade. (p. 119)

\footnotetext{
${ }^{24}$ Dentre os autores católicos que, no mesmo período, retomaram a expressão de Aristides Lobo destaca-se Desidério Deschand. Ver A situação atual da religião no Brasil. Rio de Janeiro/Paris: Garnier, 1910. p. 27-28.
} 
Sem esquecer detalhes relativos às vestimentas, peças decorativas e objetos ritualísticos, Pedro Sinzig descreve minuciosamente a reuniáo. Depois de discorrer sobre as teses aprovadas no Primeiro Congresso Nacional da Maçonaria e a expulsão dos jesuítas pela República portuguesa, o Venerável Mestre destaca o combate a admissáo dos membros da Companhia de Jesus no território brasileiro como prioridade da irmandade:

É mister que de todos os lados chovam os protestos contra o livre desembarque dos jesuítas e frades expulsos da Europa, para que o nosso DD.'. Ir.'. que, felizmente, se acha no Catete, esperança do Gr.'. Or.., marque, com pulso de ferro, nova época nos fatos da história do Brasil. Proponho, pois a nomeação de uma comissão que se vá entender com o ilustríssimo Sr. Dr. Nilo Peçanha, dd. Presidente da República, a respeito das providências a tomar-se contra o perigo iminente da invasão fradesca que nos ameaça. (p. 122)

As entusiásticas manifestaçóes de apoio à proposta são interrompidas por uma voz dissonante. Tomando a palavra o 1ํㅡㅁ Vigilante, comendador Marcos de Castro, manifesta posição contrária a do Venerável Mestre destacando, dentre outros argumentos, que ela entrava em contradição com os princípios da Grande Oriente e com a Constituição do país. Acusado por seus pares de haver, "talvez por influência de alguma pessoa de família", sucumbido ao "guante do jesuitismo", Marcos de Castro abandona a reunião.

No mesmo momento em que se realizava a reunião na loja Silêncio Noturno, Judith e Dulce trocavam confidências, manifestando sua preocupação com o pai que tinha ido se encontrar "com aqueles tais amigos que lhe fazem tanto mal". Os problemas de Judith e Dulce, no entanto, náo se comparavam aos que eram enfrentados por D. Helena e Trudinha: a última quase fora estuprada pelo filho de um fazendeiro da região, numa experiência traumática que contribuiu para agravar o estado de saúde das duas.

A segunda parte de Não desanimar! se inicia com uma recepção na casa dos Castro Moreira. Antônio, Dulce, Judith e seu noivo, o oficial da marinha Alfredo Rosa de Sales, dialogam a respeito da implantação da república portuguesa: tema que abre a possibilidade para que Alfredo faça um longo discurso contra as multidóes que se "agitavam em febre" sem tempo para "cuidar dos interesses da alma"; "os cavalheiros distintos, da nossa melhor sociedade" que só se ocupavam de seus "próprios interesses materiais"; as massas que se recusavam a comparecer às igrejas, mas lotavam os cinemas que apresentavam "insultos à fé como o filme Xisto V"; os leitores ávidos de "brochuras, revistas, (e) jornais ilustrados" de conteúdo imoral; "o Medeiros de Albuquerque, o Constantino Alves, e outros" que, nas páginas dos jornais, repetiam "o realejo de suas verrinas contra a religião revelada". Buscando reafirmar sua condição de "livre pensador", Antônio tenta rebater o discurso de Alfredo, mas é facilmente vencido pelos argumentos dos católicos presentes. Terminada a recepção, antes 
de deitar-se sobre o "duro assoalho" em que dormia, "cumprindo [...] promessa heroica", Dulce relembra o episódio em suas oraçóes:

- Seja hoje em ação de graças a Ti, meu doce Jesus, que eu me deite nesta cama. Deste-me um auxiliar no combate pela salvação da alma de papai... de papai... e também ele ouviu táo bem! Agradeço-te, meu doce Jesus... Ah! Sim, como, como te agradeço!... (p. 159)

Em sua residência, o comendador Marcos de Castro lê os protestos contra a proibição da entrada dos jesuítas em território brasileiro publicados pelos diários. Conversando com Alfredo, que havia sido transferido para o dreadnought São Paulo, Marcos de Castro manifesta-se contra a proibição que, imposta pelos maçons, prejudicaria a imagem do país no exterior. Encorajado pela indignação do "sogro", Alfredo sugere ao mesmo que se desligue da maçonaria: proposta que é prontamente recusada. Esse insucesso não diminui o ímpeto de Alfredo, que estimula Judith e Dulce a organizarem um grupo de repúdio à proibição do ingresso dos jesuítas "portugueses" no Brasil.

Preocupado com sua família, Antônio de Barros decide retornar ao planalto catarinense. Durante a viagem, o advogado tem oportunidade de refletir sobre o amor que sentia por Dulce lamentando que ela, adepta do catolicismo, jamais viesse se unir a "um homem sem religião". Recusando a hipótese de uma conversão oportunista, só lhe restava como alternativa "estudar bem a religiấo, convencer-se de sua verdade, praticá-la, enfim, mas praticá-la por convicção e não por interesse". Depois de cumprir um longo e penoso trajeto, Antônio chega à fazenda Sáo Januário deparando-se com uma tragédia: Trudinha havia falecido e sua mãe estava à beira da morte.

Ignorando o drama vivido por seu amado, Dulce se mobiliza no recolhimento de assinaturas contra a proibição do ingresso de jesuítas no território brasileiro. Dirigindo-se à casa de Julinha Rodrigues, Dulce a surpreende durante a leitura de O Malho: revista que Julinha concorda em lançar ao fogo, depois de ser duramente censurada pela amiga. Obtida a assinatura de Julinha, que também se comprometera a nunca mais ler publicaçôes infames e imorais, Dulce se junta ao grupo de mulheres encarregado de levar o documento com mais de 10 mil assinaturas a Nilo Peçanha. Recebidas no Palácio do Catete, as mulheres passam uma descompostura no "presidente da República" que, "em posição penosa", é obrigado a "ouvir, com o sorriso nos lábios, a acusação tremenda que lhe fazia a parte mais distinta da sociedade da capital do país". Poucas horas depois do encontro o grupo de senhoras católicas colhe os primeiros resultados de sua mobilizaçáa: acenando uma mudança de conduta, o governo brasileiro permitira o desembarque de dois jesuítas que haviam chegado ao Brasil no navio Orissa.

No planalto catarinense, Antônio de Barros tenta superar a morte da irmã e o agravamento da doença da mãe, lamentando não possuir a "mesma fé robusta" de seus amigos 
católicos. Encorajado pelo médico da mãe, que destaca como "uma radical mudança de ares" poderia beneficiar Helena, Antônio começa a avaliar a possibilidade de mudar-se para o Rio de Janeiro.

A pedido da mãe, Antônio de Barros se dirige ao Convento de Lages para solicitar que um frade rezasse uma missa na São Januário. Retornando à fazenda, ao lado de frei José, Antônio expóe suas angústias ao sacerdote encarregado de oficiar o ritual. Realizada no quarto de Trudinha, a missa leva o personagem a experimentar sensaçóes semelhantes às que havia vivenciado na Paixão de Oberammergau e, tomado por forte emoção, Antônio clama pela conversão que poderia ajudá-lo a suportar seus sofrimentos:

— Meu Deus e meu Senhor!... Creio... creio em Ti!... Não, eu não creio ainda, não quero nem posso mentir-te... Mas, ah! Como desejaria crer! Crer em tua presença real, crer firmemente que aqui estás, em minha fazenda, diante de mim!... Cristo, se de fato aqui estás, se me vês e me ouves, escuta-me! Olha com olhos misericordiosos para minha fraqueza e meu orgulho! Se aqui estás diante de mim, oh! Tu, Senhor do céu e da terra, faze com que te conheça, que te saiba e possa servir!... Cristo, Jesus! Socorre-me e salva-me! ... (p. 209)

Se Antônio ainda hesitava em abraçar o catolicismo, uma conversão era apressada por eventos trágicos na capital do país. Em 23 de novembro de 1910, convocado a cumprir uma missão no Minas Gerais, Alfredo de Salles ouve uma "forte algazarra" e tiros ao aproximar-se do navio. Subindo ao convés do dreadnought, Alfredo se une a um grupo que tenta, inutilmente, conter os amotinados da Revolta da Chibata e salvar o comandante Baptista das Neves, que é abatido por um tiro e por um "golpe de machadinha". Arremessado por sobre a amurada do navio, Alfredo consegue chegar até o cais. Dirigindo-se ao Arsenal da Marinha, Alfredo relata os acontecimentos ao ministro da Guerra, acompanhando-o a uma reuniáo de emergência com o "novo presidente da República, poucos dias antes empossado". Hermes da Fonseca ouve atentamente o relato de Alfredo que é interrompido pela chegada de informes ainda mais estarrecedores: o dreadnought São Paulo, o scout Bahia, os couraçados Floriano e Deodoro, os cruzadores República e Tiradentes e os navios-escola Benjamin Constant e Primeiro de Março haviam se unido à rebeliáo contra o governo, que só podia contar com o apoio dos navios Rio Grande do Sul, Barroso, Tamoyo e Tymbira.

Misturadas a boatos, as más notícias espalhavam-se pelo Rio de Janeiro provocando pânico na população. Em sua residência, Marcos de Castro e Dulce conversam sobre a revolta, interpretando-a como desdobramento de uma crise mais profunda:

— Não me surpreende nada, papai. Um homem religioso jamais recorre à violência, jamais se torna revolucionário, não trai jamais seus superiores. Religioso e revoltoso são coisas que realmente se repelem. 
- Nisso tens razão, minha filha. Oxalá os oficiais também tratassem melhor os pobres marinheiros! Por que não observam a disposição da lei, que proíbe o uso da chibata aviltante? - Tu bem sabes, papai, como toda a crueldade me indigna e repugna. Mas, dize-me, que poderão os oficiais fazer, afinal de contas, se não são obedecidos?

- Deveriam castigar, mas não tão cruelmente.

- Sim, mas o homem que não obedece, em respeito à legítima autoridade, isto é, a Deus, forçosamente se rebelará contra qualquer castigo. Se não há Deus, ou se não se ensina obedecer a ele, ninguém pode nos forçar a obedecer a quem quer que seja, neste mundo...

- Mas a ordem social, minha filha...

- Que ordem social, papai! Cada qual a compreende e interpreta de maneira diferente. Os anarquistas esforçam-se por destruí-la a ferro e fogo; os socialistas tentam transformá-la em uma utopia irrealizável; os partidos políticos visam apenas os próprios interesses, e os dos seus amigos, e não os do país e do bem público...

- A própria razão obriga à observância rigorosa de certas leis.

— Sim?... Então o ladrão, que entende injusta a distribuição desigual dos bens deste mundo; então o devasso, que afronta a moral, cobiçando o que lhe náo é devido; o usurário, que armazena tesouros à custa alheia; todos esses seguem os ditames de sua razão pessoal... Sem crença absoluta em Deus, e sem obediência completa a ele, a vida social será uma balbúrdia, uma verdadeira revolução de todos contra todos... (p. 218-219)

Insistindo na separação entre Igreja e Estado e recusando submeter-se à autoridade de Deus, a república destruíra os pilares que sustentavam a sociedade brasileira expondo-a à anarquia, à violência e à revolução. Servindo-se da "licença concedida aos romancistas" e completando as lacunas do "quadro" construído pelos jornalistas e historiadores, Pedro Sinzig reafirma em seu "romance contemporâneo" os argumentos expostos em Vozes de Petrópolis e em outros de seus ensaios. No discurso da personagem Dulce repercutem os ecos da Quanta Cura: "E, quando na sociedade civil é desterrada a religião e ainda repudiada a doutrina e autoridade da mesma revelação, também se obscurece e até se perde a verdadeira ideia da justiça e do direito, em lugar da qual triunfam a força e a violência". ${ }^{25}$ Sugerida por Pedro Sinzig, essa relação é percebida de forma mais clara se, recorrendo a Roberto Romano, lembrarmos que:

[...] o arrazoado de Pio IX não se distancia demasiado das posturas antiburguesas e autoritárias de Bonald, De Maistre e Donoso Cortés. Desde que não há mais legitimidade e Deus não é reconhecido, só resta aos homens a ditadura e a força física. Nessa visão, a humanidade, deixada aos seus próprios cuidados, solitária, sem o Outro transcendente, só poderia ser

${ }_{25}$ Pio X, Quanta Cura. Disponível em: <http://www.paroquias.org/documentos/index.php?vsec=ENC\& vid=27>. Acesso em: 8 dez. 2010. 
perfeitamente descrita pelas palavras de Donoso Cortés: uma "nave sem meta, cheia de gente sediciosa, vulgar e recrutada pela força, que canta e dança até que o raio divino fulmine a plebe rebelde e torne a reinar o Silêncio". ${ }^{26}$

Depois de semear ventos, a república descristianizada, versão abrasileirada da Stultifera Navis, colhia a tempestade de projéteis disparados pelos amotinados da Revolta da Chibata. A queda de um obus em local próximo à residência dos Castro Moreira interrompe o diálogo entre pai e filha, que decidem dormir. No meio da noite, os dois são acordados por um morteiro que atinge sua casa. Correndo para o quarto da filha, o comendador a surpreende deitada no chão nu, compreendendo imediatamente o significado do ato: uma penitência em prol de sua conversão ao catolicismo. Emocionado, Marcos de Castro vai até seu escritório, arranca da escrivaninha os documentos que atestavam sua afiliação à maçonaria e os entrega a Dulce para destruí-los. Na manhã seguinte pai e filha se dirigem à capela do Colégio Santo Inácio, onde se confessam e recebem os santíssimos sacramentos.

Na Câmara dos Deputados, o tenente Alfredo de Salles assiste aos debates sobre a proposta de concessão de "anistia aos revoltosos, que se achavam ainda de posse dos poderosos dreadnoughts, cujos canhóes, ameaçadoramente, dirigiam suas enormes bocas de fogo para a cidade, e não pouco amedrontavam os próprios legisladores". ${ }^{27}$ Decepcionados com o resultado da votação, 119 votos a favor e 19 contra a anistia, Alfredo de Salles e outros oficiais agendam uma reunião no Clube Naval, mas são impedidos de realizá-la por seus superiores que ordenam a retenção de "todos os oficiais da Armada, no Arsenal de Marinha": depois de se vergar-se aos "marinheiros rebeldes armados", o governo tentava demonstrar autoridade e coragem reprimindo "oficiais disciplinados e sem armas!".

Instalado no Rio de Janeiro, Antônio da Costa Barros recebe a visita de Dulce, que o auxiliava a cuidar de sua mãe que, desde a morte de Trudinha, ficara muda. Quando Dulce sugere que D. Helena apelasse a Nossa Senhora Aparecida para reconquistar sua saúde e sua fala, Antônio é invadido por pensamentos revelados ao leitor pelo narrador do romance:

Antônio já não era o mesmo homem que fora incrédulo à Eu ropa. O que vira em Oberammergau, em Lisboa, o que ouvira dos lábios de Frei Estevam, o exemplo do tenente, e, principalmente, além do exemplo de Dulce, tudo aquilo se passara em sua volta à terra natal, a morte da irmá, a doença da mãe, a conversa que teve com Frei José, a Missa a que assistira na fazenda, e, last not least, as sérias reflexóes que, ao lado da mãe privada da fala fizera durante a longa viagem, tudo isso lhe modificara o antigo modo de pensar e de ver as coisas, e, se bem que não houvesse ainda resolvido a mudar praticamente de opiniáo, começara a encarar com outros olhos a prática da religião. (p. 236)

\footnotetext{
${ }^{26}$ ROMANO, Roberto. Brasil: Igreja contra Estado. São Paulo: Kairós, 1979. p. 86.

${ }^{27}$ SINZIG, Pedro, op. cit., p. 227.
} 
Antônio concorda com a viagem a Nossa Senhora Aparecida e, entusiasmada pela aceitação de sua proposta, Dulce lhe sugere realizar um ato que traria benefícios a ele e a mãe: confessar e comungar na Basílica de Aparecida.

No curto trajeto que separava sua casa da de Antônio, Dulce é abordada por um garoto maltrapilho cuja mãe, acamada depois de haver recebido uma surra do marido, desejava falar-lhe. Admirando Dulce pela sua caridade e devoção aos humildes, a pobre mulher desejava preveni-la contra um perigo que ameaçava o tenente Alfredo de Salles: o marido, marujo que se tornava extremamente mau após o consumo de álcool, havia lhe contado que "os soldados do batalhão naval e os marinheiros dos navios de guerra" iriam "revoltar-se [...] e matar os oficiais todos".

Alertado por Dulce, o general Menna Barreto não consegue evitar o levante, que só é contido com o bombardeio da Ilha das Cobras. Analisando o episódio num diálogo com a esposa, Marcos de Castro demonstra haver assimilado as liçóes de Dulce, reafirmando sua conversão ao catolicismo:

É um verdadeiro horror essa história de revoltas [...]. Afinal de contas, já hoje, no entanto, não me admiram muito. A chibata revolta, e têm razão os que se revoltam contra ela. Mas que meio encontra o oficial para fazer-se obedecido? O capelão, no exército ou na armada, usaria de meios suasórios e, mesmo quando ofendido, perdoaria o agravo e prosseguiria em sua missão salvadora. Mas um oficial não pode nem deve deixar-se desfeitear impunemente.

— São coisas essas bem tristes — respondeu D. Sinhá. — Não podiam então os pobres homens viver em paz?

- Os interesses se chocam, e daí se originam as lutas. Estou mesmo convencido de que sem a religiáo não poderá subsistir o estado. A polícia é praticamente impotente para repelir as audácias dos perversos. (p. 248)

Acompanhados por Dulce, Judith e Alfredo, Antônio e sua mãe chegam à Basílica de Aparecida. No interior do templo, Dulce clama não apenas pela cura de Helena, mas também pela conversão de Antônio a quem, desde algum tempo, amava. Absorta em suas oraçôes, Dulce é interrompida por Judith, que chama sua atenção para Antônio, que se ajoelha no confessionário:

Começou entáo a santa missa. Pela altura do Ofertório, o doutor (Antônio) deixou o confessionário. Parecia que náo tinha mais olhos para coisa alguma, e foi ajoelhar-se em um ponto um tanto afastado de todos... Parecia rezar como o capitão do Evangelho: Eu não sou digno, Senhor!...

Ao tríplice sinal da campainha para a Comunhão, pela primeira vez, Antônio acompanhou sua Mãe à Mesa Eucarística, ajoelhou-se bem ao lado, tendo Dulce à esquerda, depois Judith, depois Alfredo... 
E os anjos do céu se alegraram pela volta de uma ovelha perdida ao aprisco do Divino Pastor... (p. 257-258)

Descendo a íngreme ladeira que dava acesso à Basílica, Dulce e Helena sofrem um acidente com uma das precárias "carroças" que transportavam os romeiros na cidade. Recompondo-se do choque, Dulce se dirige a Helena que, em alto e bom som, atribui o salvamento das duas à intervenção de Nossa Senhora de Aparecida. Um duplo milagre havia se operado: as mulheres haviam escapado ilesas e Helena recuperara a fala. Emocionados, Dulce, Helena, Antônio, Judith e Alfredo retornam à Basílica para agradecer à Nossa Senhora pelas graças recebidas:

Entre aclamaçóes quase convulsas de uma alegria infinita, de uma surpresa sem limites, dirigiram-se todos de novo ao templo. O povo, embora já acostumado aos frequentes milagres de Nossa Senhora, saía correndo, curioso, das casas, e muitos acompanharam a família até ao Santuário, a unirem suas oraçóes em ação de graças às dos felizes romeiros.

- Como lhe hei de agradecer, D. Dulce? - disse o doutor, ao saírem novamente da Basílica, e tomando a mão da donzela, que beijou respeitosa e carinhosamente.

— Agradecer-me a mim?... Mas a mim não tem nada que agradecer!...

— Sim, a senhora merece... merece...

Não ousou continuar, a concluir a frase. Novo rubor tingiu as faces da jovem... A sua mãozinha mimosa tremia nas dele... e quando, num impetuoso movimento, ele lha apertou com força, ela retribuiu-lhe, embora levemente a carícia...

— Dulce!... posso então esperar... Posso crer que... Oh! Como sou feliz!

Ela então lhe sorriu deliciosamente.

— Dulce!... Minha Dulce!... Minha querida Dulce! — exclamou o doutor, apertando a moça ao peito, em plena praça pública, e apesar dos olhares admirados dos populares, que os contemplavam...

- Amas-me muito, Dulce?

— Sim... eu te amo... e desde há muito tempo, Antônio!...

E um beijo, um grande e casto beijo, selou as juras dos noivos, em plena rua, diante da milagrosa Basílica... (p. 260/261)

Com a formalização da união entre Antônio e Dulce, Não desanimar! chega ao seu final. Trocado "em plena praça pública", no meio do "povo" que "havia acompanhado a família até ao Santuário", o beijo do casal expressa uma das metas que Pedro Sinzig buscava atingir com seus "romances contemporâneos": a recristianização das elites republicanas que, reintegradas ao "rebanho" pelo influxo decisivo das mulheres, podiam novamente entrar em comunhão com o "povo". 


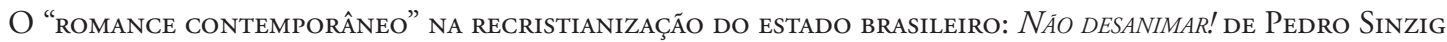

\section{Referências bibliográficas}

ALMEIDA, Claudio Aguiar. Meios de comunicação católicos na construção de uma ordem autoritária: 1907/1937. Tese (Doutorado em História) — FFLCH-USP, São Paulo, 2002. BEUTTENMÜLLER, Leonila Linhares. Frei Pedro Sinzig O.F.M. Petrópolis: Vozes, 1955. DALTON, Margareth Stieg. Catholicism, Popular Culture, and the Arts in Germany: 18801933. Notre Dame: University of Notre Dame Press, 2004.

DESCHAND, Desidério. A situação atual da religião no Brasil. Rio de Janeiro/Paris: Garnier, 1910.

DESCHAND, Desidério. Os grandes sábios e a fé na época contemporânea. Tournai: Sociedade de S. João Evangelista/Desclée e Cia, s/d.

MICELI, Sérgio. A elite eclesiástica brasileira. São Paulo: Companhia das Letras, 2009.

MOURA, Sérgio Lobo de; ALMEIDA, José Maria Gouvêa de Almeida. A Igreja na Primeira República. In: FAUSTO, Bóris (Org.). O Brasil republicano: sociedade e instituiçôes (1889/1930). Rio de Janeiro: Bertrand Brasil, 1990, t. III, v. 2 (Coleção HGCB).

PAIVA, Aparecida Paiva. A voz do veto: a censura católica de romances. Belo Horizonte: Autêntica, 1997.

ROMANO, Roberto. Brasil: Igreja contra Estado. São Paulo: Kairós, 1979. p. 86.

SANTOS, Maria Margarete dos. Os jardins abençoados de um franciscano, discurso sobre a leitura de Frei Pedro Sinzig: 1915-1923. Dissertação (Mestrado em História) — USP, São Paulo, 2005.

SINZIG, Pedro. Passo decisivo. Vozes de Petrópolis, Petrópolis, p. 439 a 445, jul. 1909 a jun. 1910.

. Reminiscências dum frade. Petrópolis: Vozes de Petrópolis, 1925.

Ancilla Domini. In: Os nossos escritores. Rio de Janeiro: Centro da Boa Imprensa, 1917.

- Através dos romances: Guia para as consciências. Petrópolis: Vozes de Petrópolis, 1923.

. Não desanimar!. 3. edição. Petrópolis: Vozes de Petrópolis, 1925.

. Notas sobre O Filho de Agar. In: Vozes de Petrópolis, p. 1027-1028, jul./dez. 1912.

. Os romances das Vozes de Petrópolis. Vozes de Petrópolis. Petrópolis: p. 1095-1098, jul./dez. 1912.

- Para orientar o leitor. In: O thaumaturgo Santo Antonio. Petrópolis: Centro da Boa Imprensa, 1922. 